\title{
Faculty Development Needs as Perceived by Departmental Heads, Teachers, and Students of Pakistani Universities
}

\author{
${ }^{1}$ Shaukat Ali Raza, ${ }^{2}$ Fauzia Naheed Khawaja \\ ${ }^{1}$ Department of Business Education, IER University of the Punjab Lahore, Pakistan \\ ${ }^{2}$ Hailey College of Banking \& Finance University of the Punjab Lahore, Pakistan
}

\begin{abstract}
The study investigated the perceptions of 67 departmental heads, 567 teachers, and 670 students randomly selected from 67 departments of 33 faculties of 15 public sector universities of Pakistan, regarding the need for instructional, professional and organizational development of faculty. Three self-constructed questionnaires, for which Cronbatch's Alpha reliability coefficients were found as $0.8418,0.8346$ and 0.7812 respectively, were used for data collection. Mean scores, alpha coefficients and correlations were calculated for the three sub-scales namely instructional development, professional development and organizational development. One-sample $t$-test, independent samples $t$-test and one-way ANOVA were employed for significance and variance analysis. An overall high need for faculty development at universities of Pakistan is pointed out by respondents. Instructional development is indicated by the respondents as having the highest degree of need followed by organizational development and Professional development in order of preference of the respondents. Pakistani universities need to take initiatives for developing their faculty to fulfill the demand of stakeholders for realizing the national higher education objectives.
\end{abstract}

\section{Introduction}

Faculty development is an endless process that enhances the productivity of academics [3] [16] for helping them play their instructional, professional, and organizational roles [15] [6]. Faculty development sharpens conceptual, human, and technical skills of university teachers [2] [15] [14]. These skills enable faculty to produce graduates capable of satisfying the demands of employers [15] [16]. Penetration of such graduates in the job market leads to social and economic development of society [17] to realize the national higher education objectives [16]. Keeping in view the importance of faculty development, this study explored the degree of need for faculty development at Pakistani universities as perceived by departmental heads, teachers, and students.

\section{Review of literature}

This section elaborates the concept and process of faculty development and highlights the way to assess the need for faculty development.

\subsection{Concept of Faculty Development}

Faculty development, the 'buzz word' of $21^{\text {st }}$ century higher education [2], is rooted in early 1800 s as a faculty renewal strategy focusing mainly on subject matter [9]. But, now, by adding life-long education of the faculty members that changes its status from a product to a process, it surpasses orientation and training. It draws upon disciplines like human resource management, organizational behavior, and assessment [2] to set objectives and develop strategies for faculty development program. Faculty development covers improvement of teaching and education, research and scholorship in discipline, academic leadership and management, and other affairs like recruitment, advancement, retention, and vitality of faculty addressing their roles as teachers, educators, leaders, administrators and researchers [21].

Right from the fundamental work of Bergquist and Phillips [8], the literature on faculty development (such as Laursen, \& Rocque, [13]; Raza, Majid \& Zia, [15]; Raza \& Naqvi, [14]; Anna Maria College, [6]) divides the above cited dimensions in three categories namely instructional, professional, and organizational development of university teachers. Instructional (or teaching) development covers clinical skills for teaching; professional (or scholarship) development causes sophistication in academic discipline and professional growth; and organizational (or service) development ensures growth of faculty as members 
of an academic community at a particular university setting.

\subsection{Process of Faculty Development}

Faculty development process involves decisions and actions regarding the level of activity, approaches and strategies to be followed, and incentives and evaluation/feedback patterns of a program to be launched. Faculty development is not a unilateral activity and it could be made affective only if it is launched simultaneously at individual, department, and university level [20] [2].

Adoption of a faculty development approach is also a big issue as there are regional, national, interdisciplinary, and institutional perspectives [16] in faculty development. Selection of a faculty development strategy is still another issue. Gray and Drew [10] and Ali [2] have suggested faculty development strategies ranging from conducting workshops to the establishment of learning communities of teachers. The duration of faculty development activities is also an administrative variable. Such activities may be arranged on daily, weekly, and monthly bases with varied time durations [2]. Similarly, evaluation of faculty development initiatives needs special consideration. A 360-degree evaluation suggested by Kodwani and Sing [12] could be a better solution if it is conducted at the end of a program by organizers and at the university department by heads, teachers, and students [2].

Despite its inevitability, it is not easy to launch a faculty development program. Ali [2] has referred different studies pointing out lack of management commitment, financial instability, workload, faculty attitude, and lack of planning, implementation and evaluation potential as key problems.

The gist of a faculty development literature could be better visualized from Figure 1 as depicted by Ali [2].

\subsection{Assessing Need for Faculty Development}

Laursen and Rocque [13] and Ali [2] provide an extended description of need for faculty development at universities. The need for faculty development at Pakistani universities gets ground from the fact that faculty is being inducted without any formal training [15] [16] and development facilities currently available there are desolately inadequate [16]. Consequent upon that, the performance of these universities is substandard and stakeholders are demanding for improvement [16] which is possible only through faculty development to make faculty as well as the university more productive [1] [16] [21].
Assessment of this need for faculty development is actually identifying the gap between the standard and current performance of faculty [1]. Kodwani and Sing [12] provide a three-step need assessment model based on analysis of the existing attributes of the employees (the individual); current job analysis (the process); and organization analysis (the organization). This framework is similar to the pioneer work of Bergquist and Phillips [8] that provided a well-documented description of need assessment for instructional development, professional development, and organizational development of faculty by teachers themselves, departmental heads, and above all students...the fee paying customers [11] [16].

This paper is derived from the $\mathrm{PhD}$ thesis of the first researcher with the basic purpose to assess the above described need for faculty development at universities of Pakistan as perceived by departmental heads, teachers, and students. More specifically, the study answered the following questions:

1. Is there a significant need for faculty development at universities of Pakistan as indicated by departmental heads, teachers, and students regarding instructional development, professional development, and organizational development?

2. Is there any significant difference of opinion among the departmental heads, teachers, and students over the need for instructional development, professional development, and organizational development for universities of Pakistan?

3. Is there any significant difference of opinion over the need for faculty development among the respondents in terms of gender, qualification, designation, degree program, discipline, university teaching experience, administrative experience, and university as independent variables?

\section{Methodology}

This section deals in constitution of sample from the population, development of instrument of the study and the data analysis procedures.

\subsection{Sample}

The current study is based on the Primary data collected from departmental heads, teachers [9]) and students [11] of 15 public sector universities of Pakistan. As a first step of the multistage sampling procedure [16], 30\% stratified random sampling was used to select 15 universities (03 out of 09 from Sindh; 01 out of 05 from Baluchistan; 05 out of 18 from Punjab; 03 out of 09 from Khaibar Pakhtoonkhwah; and 03 out of 09 public 


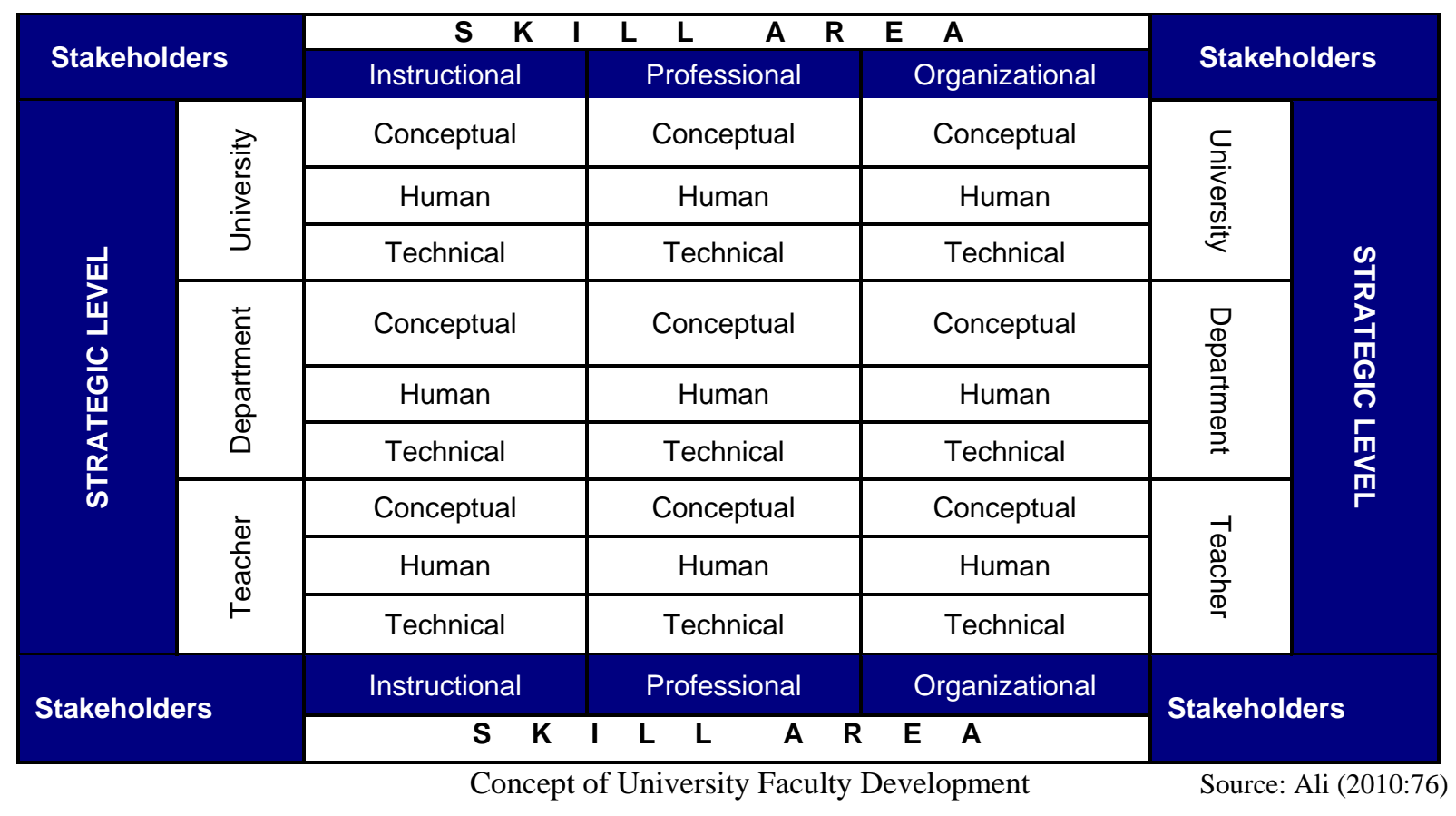

Figure 1. The gist of a faculty development literature

Table 1. Correlations of factors with total scale for faculty development

\begin{tabular}{|c|c|c|c|}
\hline Sub-Scales & $\begin{array}{c}\text { Professional } \\
\text { Development }\end{array}$ & $\begin{array}{c}\text { Organizational } \\
\text { Development }\end{array}$ & Faculty Development \\
\hline Instructional Development & $0.493^{* *}$ & $0.396^{* *}$ & $0.794^{* *}$ \\
\hline Professional Development & & $0.269^{* *}$ & $0.725^{* *}$ \\
\hline Organizational Development & & $0.712^{* *}$ \\
\hline$* *$ Correlation is significant at the 0.01 level (2-tailed). & \\
\hline
\end{tabular}

Table 2. Mean scores and one-sample t-values against respondents for Sub-Scales of Faculty Development

\begin{tabular}{|c|c|c|c|c|c|}
\hline Sub-Scales & Alpha & Mean & SD & df & $t$-values \\
\hline Instructional development & 0.862 & 4.257 & 0.658 & 1303 & $68.511^{*}$ \\
\hline Organizational development & 0.683 & 3.964 & 0.718 & 633 & $33.805^{*}$ \\
\hline Professional development & 0.708 & 3.822 & 0.465 & 633 & $44.500^{*}$ \\
\hline${ }^{*} p<0.05$
\end{tabular}


universities from Islamabad). Secondly, one-third (33) faculties were randomly selected from (99) available faculties of sample universities. Thirdly, one-third (67) departments were randomly selected from (193) available departments in the sample faculties. Lastly, 67 departmental heads, 577 (from $80 \%$ each department) teachers, and 670 (10 from each department) students were selected from final semesters of available Graduate, Master, MPhil, and $\mathrm{PhD}$ degree programs.

\subsection{Instruments}

Data were collected through three selfconstructed questionnaires developed in three phases. At the outset, inventories of faculty competencies were obtained from the literature on faculty development [19] [2]. These competencies were put in a questionnaire with 44 items divided in instructional; professional; and organizational development as three components of faculty development.

Keeping in view the value of focus groups as highlighted in the literature on faculty development, a focus group interview [2] [16] of 21 students taken three each from arts; science; commerce; law; engineering; education; and agriculture faculties of the three universities of the Punjab was conducted at the department of Business Education of the University of the Punjab, for getting their opinion on items related to instructional development. Similarly, another focus group of 12 teachers from education, law, and commerce faculties of the University of the Punjab was conducted to gather opinion on items for all the three components. Afterwards, a panel of 18 experts from different disciplines both from local and foreign universities was also consulted using Delphi Technique [2] for validation of the questionnaire. As a consequence of focus groups and expert opinion, the inventory of items was reduced to 34 and the questionnaires based on 5point Likert scale were constructed for heads, teachers, and students with same items [8] [2] with the exception that items related to professional and organizational development were not given to students. These questionnaires were piloted at ten departmental heads; sixty teachers; and seventy students which resulted in $28(14+10+4)$ items for the three sub-scales of faculty development respectively after deleting weak items with Alpha scores 0.4 and below [16]. There was also one open-ended question for students to suggest any thing else for the instructional development of their teachers.

\subsection{Data Analysis}

Responses were quantified as 5 for very high; 4 for high; 03 for medium; 02 for low; and 01 for very low degree of need as given on the three scales developed for measuring the need for faculty development. Mean score 03.0 was taken as the cut point [15] [16] and for mean values higher than 3.00 , the degree of need for faculty development was considered as adequate; whereas, for mean values equal to 3.00 or below, the degree of need for faculty development was considered as inadequate [2] [16].

\section{Results and Discussion}

Respondents included 67 heads (5\%), 567 teachers (44\%), and 670 students (51\%) respectively among which $62 \%$ respondents were male and $38 \%$ were female. Majority of respondents $(44 \%)$ in the three categories were from social sciences; having MA/MSc degrees (60\%); serving as lecturers (41\%); with 6-10 years of teaching (28\%); 6-10 years of administrative experience (49\%); and belonged to Karachi University (23\%).

\subsection{Exploring Faculty Development Need}

Correlations and alpha values were calculated for significance of sub-scales. The intra sub-scale correlations (See Table 1) are weaker against their correlations with total scale for faculty development needs. Alpha values for instructional development (0.862), professional development (0.708), and organizational development (0.683) are above minimum acceptance level (0.6) for subscales. Similarly, the mean scores $(4.257,3.822$, and 3.964) for these sub-scales are significantly above the referred value 03 . These conditions signify the construct validity and internal consistency of the sub-scales and an adequate degree of need for faculty development [11] [15] [14] [16] [18]. As 04 on the Likert scale used for this study reflected a high degree of need, the mean scores for all the three sub-scales reflect an overall (4.014) high degree of need for instructional development, professional development, and organizational development at the universities of Pakistan as indicated by departmental heads, teachers, and students. These results are consistent with Ali [2], Raza, Majid, \& Zia [15], Raza and Naqvi [14], Raza, Naqvi, and Lodhi [16] and make a point to answer the first research question of the study.

\subsection{Comparing Faculty Development Need}

One-sample statistics (see Table 2) produced mean scores for the three sub-scales significantly above the referred value (03) reflecting an adequate degree of need of faculty for development in these components where instructional development 
(4.257) is at the highest degree of need followed by organizational development (3.964), and professional development (3.822). The mean score 4.257 reflects a high to very high degree need for faculty development in instruction as indicated by departmental heads, teachers, and students. This tendency is similar to Ayers [7], Raza, Zain, \& Zia [15], Raza, Naqvi, and Lodhi [16]). The post-hoc analysis in one-way ANOVA identified students as expressing significant higher need for instructional development sub-scale as compared with teachers. As students were asked to give opinion only for instructional development, students from all degree programs have unanimously pointed out this high instructional need. One possible reason for this tendency could be the partial satisfaction of students as the fee paying customers [11] [2] with the instructional performance of their teachers [2] [15] [16]. Analysis of open-ended question too supports this reason where students are demanding the development of their teachers in student-teacher relationship as a consequence of a major shift in higher education clientele [20] [16].

Mean scores for professional and organizational scores are almost equal and indicate the similar level of need for faculty development in these areas which is verified by the post-hoc test where no significant difference of opinion was found between heads and teachers over the need for professional and organizational development. This tendency may reflect the serious intention of heads and teachers towards their development in these components [2]. But, for the purpose of comparison, organizational development (with 3.964) needs more attention of the higher education managers [5] [2]. The situation also highlights the self-efforts of heads and teachers of universities of Pakistan for their professional development as it got the lowest mean (3.822). This tendency is similar to the results of Allen [4] and Raza and Naqvi [14]. In this way, the second research question gets the answer through all these findings.

\subsection{Analysis of Independent Variables}

Analysis of sub-scales in terms of independent variables revealed no significance difference of opinion among male and female respondents regarding need for instructional, professional, and organizational development. It means that all respondents are unanimously emphasizing on the need for faculty development at universities of Pakistan [2] [16].

In qualification, designation, and teaching experience categories of heads and teachers, a significant higher need for instructional and professional development is identified by faculty members having MA/MSc and MPhil degrees; who are lecturers and assistant professors; and those with 1-5 and 6-10 years of teaching experience.
Whereas $\mathrm{PhD}$ degree holders; associates and professors; and those having 16-20 years of teaching experiences have identified significant higher need in organizational development. These findings are complementary to each other. Though universities have started direct induction of PhDs, even then majority of MA/MPhil teachers are lecturers and assistant professors. And these are the faculty members who possess $1-5$ or 6-10 years of teaching experience. Owing to these feachers, such people need to strengthen their instruction and grow in the discipline. That is why they have identified higher need for instructional and professional development. But associates and professors, who are usually PhDs and hold longer teaching experiences, intend to grow vertically up in the university hierarchy. Therefore, they are more interested in organizational development as compared with junior faculty. Administrative experience analysis revealed that heads have same opinion regarding need for instructional, professional, and organizational development.

Discipline analysis revealed that agriculture, social sciences, and all sample disciplines except engineering have pointed out significant higher need for instructional development, professional development, and organizational development respectively. These findings reflect weak instructional, professional, and organizational competencies of agriculture and social sciences faculty at the one hand and relatively better condition of engineering faculty in these areas especially professional and organizational development areas and university analysis below supports this argument.

In university analysis, respondents from University of Baluchistan Queta, BZ University Multan, Lahore College for Women University, Agriculture University Faisalabad, University of Engineering and Technology Lahore, University of Peshawar, Bahria University, International Islamic University, Quaid-e-Azam University, and Agriculture University Faisalabad have identified significant higher need for instructional development. Respondents from 10 out of 15 sample universities of Pakistan are pointing out higher need in instructional development. These findings are consistent with Raza, Naqvi, and Lodhi, [16] and sub-scale analysis above where instructional development fell in the highest degree of need. This situation supports the argument of Raza and Naqvi [14] who report the performance of Pakistani universities below the job market standards. Respondents form Lahore College for Women University, University of Peshawar, and Quaid-e-Azam University, Islamabad, have shown significant higher need for professional development. As indicated in discipline analysis above, general universities need more professionalism. For organizational development, 
respondents from Punjab University, NWFP Agriculture University, University of Peshawar, Bahria University, and Quaid-e-Azam University have pointed out significantly higher need for organizational development and this trend to supports the relatively strong professionalism and organizational competencies of other universities especially those related to engineering discipline.

The analysis of background variables provides answer to the third research question of the current study. When all the research questions are answered, the purpose of the study is achieved.

\section{Conclusion}

Correlations and alpha values calculated for subscales signify them and their construct validity and internal consistency is well established. An overall high degree of need for instructional development, professional development, and organizational development at the universities of Pakistan is pointed out by departmental heads, teachers, and students.

Instructional development sub-scale of faculty development is highlighted by the respondent with the highest (high to very high) degree of need followed by organizational development and professional development. Students, the fee paying customers from all degree programs, have unanimously pointed out a significant higher need for instructional development sub-scale as compared with teachers that shows their partial satisfaction with the instructional performance of their teachers. They have also pointed out significant need for developing faculty in studentteacher relationship. After instructional development, organizational development is categorized as the sub-scale with the highest degree of need for faculty development whereas professional development was placed at the lowest position in this regard.

Male and female respondents showed no significance difference of opinion regarding need for instructional, professional, and organizational development. In qualification, designation, and teaching experience categories of heads and teachers, a significant higher need for instructional and professional development is identified by faculty members having MA/MSc and MPhil degrees; who are lecturers and assistant professors; and those with 1-5 and 6-10 years of teaching experience. Whereas $\mathrm{PhD}$ degree holders; associates and professors; and those having 16-20 years of teaching experiences have identified significant higher need in organizational development. Discipline analysis revealed that agriculture, social sciences, and all sample disciplines except engineering have pointed out significant higher need for instructional development, professional development, and organizational development respectively. Respondents from 10 out of 15 sample universities of Pakistan are pointing out higher need in instructional development. Respondents form general universities have pointed out higher need for professionalism. Respondents from universities related to engineering discipline are stronger in professional and organizational competencies.

\section{Recommendations}

The study has established an overall high degree of need for faculty development. Therefore universities of Pakistan are recommended to take it seriously and launch faculty development activities to fulfill the demand of the respondents, the major stake holders, to realize the national higher education objectives. Instructional, organizational, and professional development of the faculty should be carried out in order of priority as set by the respondents. More opportunities for instructional and professional development should be provided to lecturers and assistant professors whereas associates and professors should be more exposed to organizational development to cater specific needs of these layers of university faculty cadres. Social sciences and general universities should be more exposed to faculty development activities as compared with other disciplines.

\section{References}

[1] Adkoli, B. V., Al-Umran, K. U., Al-Sheikh, M. H, Deepak, K. K. Innovative Method of Needs Assessment for Faculty Development Programs in a Gulf Medical School. Education for Health, (2010). 23(3), 389. Available from: http://www.educationforhealth.net/

[2] Ali, S. Faculty Development Program for University of Pakistan: the Need to Develop a Model. PhD thesis. Lahore: University of the Punjab. Retried March 24, 2012 from http://eprints.hec.gov.pk/6072/1/4019H.htm (2010).

[3] Ali, N. S., Hodson-Carlton, K., Ryan, M., Flowers, J., Rose, M. A. and Wayda, V. Online Education: Needs Assessment for Faculty Development. The Journal of Continuing Education in Nursing. (2005). 36(1), 32-8. http://www.sarasotaintranet.usf.edu/ir/Documents /DistanceLearning/ali.pdf

[4] Allen, J. E. The New Faculty and Graduate Mentor: A Guide to Developing Teacher-Scholars for Mentors, Faculty, Administrators and Graduate Students. Stylus Publishing. (2008).

[5] Al-Turki, U., \& Duffuaa, S. Performance measures for academic departments. International Journal of Educational Management, (2003), 17(7), 330-338.

[6] Anna Maria College. Faculty Development SelfAssessment. Center for Teaching Excellence. (2011). Retrieved 27-11-2012 from https://resources. 
annamaria.edu/ documents/CTE/FACULTY\%20 DEVELOPMENT\%20NEEDS \%20ASSESSMENT.pdf

[7] Ayers, W. The hope and practice of teaching. Journal of Teacher Education, (2006), 57(3), 269-277.

[8] Bergquist, W. H., \& Phillips, S. T. Components of an Effective Faculty Development Program. Journal of Higher Education, (1975), 46(2), 177-211.

[9] Camblin, L. D., \& Steger, J. A. Rethinking faculty development. Higher Education, (2000), 39(1), 1-18.

[10] Gray, P., \& Drew, D. E. What They Didn't Teach You in Graduate School: 199 Helpful Hints for Success in Your Academic Career. (2008). Stylus Publishing.

[11] Gursoy, D., \& Umbreit, W. T. Exploring students' evaluation of teaching effectiveness: What factors are important? Journal of Hospitality \& Tourism Research, (2005), 29(1), 91-109.

[12] Kodwani, A. D., \& Sing, M. Towards Effective Training and Development in Indian Public Sector Enterprises: A Case-based Analysis. South Asian Journal of Management, (2004), 11(3), 36-56.

[13] Laursen, S, \& Rocque, B. An Assessment of Faculty Development Needs at the University of Colorado at Boulder: A Report Prepared for the LEAP Project. (2006). Retrievedd 27-11-2012 from http://www.colorado.edu/eer/ downloads/LEAPfaculty DevelopmentNeeds2006.pdf

[14] Raza, S. A. \& Naqvi, S. A. Quality of Pakistani University Graduates as Perceived by Employers: Implications for Faculty Development. Journal of Quality and Technology Management, (2011), VII(I), 5772.

[15] Raza, S. A., Majid, Z., Zia, A. Perceptions of Pakistani University Students about Roles of Academics Engaged in Imparting Development Skills: Implications for Faculty Development. Bulletin of Education \& Research. (2010), 32(2): 75-91

[16] Raza, S. A., Naqvi, A. H., \& Lodhi, A. S. Assessing Need for Teaching Development of Faculty at Universities of Pakistan: A Students' Perspective. Bulletin of Education and Research, (2011), 33(2): 4962.

[17] Raza, S. A., Zia, S. A., Naqvi, A. H., Shaikh, F. M. Human and Social Capital Development for Self Efficacy of University Graduates: Bases for Development of Society. Asian Social Science, (2011), 7(9): 244-254.

[18] Raza, S. A., Zia, S. A., Naqvi, A. H., \& Ali, A. Investigating Service Quality Initiatives of Pakistani Commercial Banks. International Business Research,(2012), 5(3): 107-113.
[19] Rosen, L. M. Instructional Development Needs Assessment. Office of Faculty and Organizational Development, Michigan State University, East Lansing. (2005). Retrieved February 28, 2007 from http://www1.provost.msu.edu/facdev/fodarchives/ 8_Nds_Assess_SURVEY_4-11.pdf.

[20] Sohail, M. S., \& Daud, S. Restructuring a higher education institution: A case study from a developing country. International Journal of Educational Management, (2006), 20(4), 279-290.

[21] University of Toronto. Faculty Development definition. 1st International Conference on $1^{\text {st }}$ International Conference on Faculty Development in the Health Profession. Toronto: Faculty of Medicine, University of Toronto. May 10-13, 2011. http://www.facultydevelopment2011.com/ (2011). 